\title{
EFFECT OF FOREST ECOSYSTEMS ON THE SNOW WATER EQUIVALENT IN RELATION TO ASPECT AND ELEVATION IN THE HUČAVA RIVER WATERSHED, POLANA BIOSPHERE RESERVE (SLOVAKIA)
}

\author{
MICHAL MIKLOŠ ${ }^{1}$, ILJA VYSKOT ${ }^{2}$, TOMÁŠ ŠATALA ${ }^{1}$, KATARÍNA KORÍSTEKOVÁ ${ }^{1,3}$, \\ MARTIN JANČO ${ }^{1,4}$, JAROSLAV ŠKVARENINA ${ }^{1}$
}

\begin{abstract}
${ }^{1}$ Department of Natural Environment, Faculty of Forestry, Technical University in Zvolen, T. G. Masaryk street 24, 96053 Zvolen, Slovak Republic; e-mail: miklosmiso@gmail.com, skvarenina@tuzvo.sk

${ }^{2}$ Department of Environmentalistics and Natural Resources (FRDIS), Faculty of Regional Development and International Studies, Mendel University in Brno, Tř. Generála Píky 2005/7, 61300 Brno, Czech Republic; e-mail: ilja. vyskot@mendelu.cz

${ }^{3}$ Department of Fire Protection, Faculty of Wood Sciences and Technology, Technical University in Zvolen, T. G. Masaryk street 24, 96053 Zvolen, Slovak Republic; e-mail: katarina.koristekova@gmail.com

${ }^{4}$ Department of Biology and General Ecology, Faculty of Ecology and Environmental Sciences, Technical University in Zvolen, T. G. Masaryk street 24, 96053 Zvolen, Slovak Republic; e-mail: martinjanco11@gmail.com
\end{abstract}

Abstract

Mikloš M., Vyskot I., Šatala T., Korísteková K., Jančo M., Škvarenina J.: Effect of forest ecosystems on the snow water equivalent in relation to aspect and elevation in the Hučava river watershed, Polana Biosphere Reserve (Slovakia). Ekológia (Bratislava), Vol. 36, No. 3, p. 268-280, 2017.

The aim of this work was to assess how forest ecosystems dominated by Norway spruce (Picea abies (L.) or European beech (Fagus sylvatica L.) affect snow water equivalent (SWE) in relation to aspect and elevation. The research plots were established in a small headwater watershed of the Hučava flow belonging to the Polana Biosphere Reserve (Central Europe, Inner Western Carpathians). The SWE values in this watershed (approximately $580-1270 \mathrm{~m}$ a.s.l.) were monitored during the three winter seasons starting from 2012-2013 to 2014-2015. The results revealed high variability in SWE and in snow cover duration between the studied seasons. The spatial variability was significantly affected by the forest ecosystem, aspect and elevation. The seasonal mean SWE value was lower by about $50-60 \%$ in the spruce forests and by about $21-30 \%$ in the beech forests compared to the open areas (100\%). Over the whole seasons, the whole watershed mean SWE value on the slopes with the northern aspect was mostly higher compared to the slopes with the southern aspect. The effect of aspect was significant mainly in the open areas and in the forests dominated by European beech during the ablation periods of every season. In the case of the sufficient snow cover, the mean SWE value always increased with elevation. The elevation gradient of SWE was steepest at the open areas of the watershed in the peaks of the winter seasons. The threeseason mean value of SWE elevation gradient (per $100 \mathrm{~m}$ ) at the time of snow accumulation peak was equal to $16 \mathrm{~mm}$ in the spruce forests, $20 \mathrm{~mm}$ in the beech forests and $26 \mathrm{~mm}$ in the open areas. The research revealed that SWE is significantly affected by the forest ecosystem whilst its effect is dependent on the occurrence of dominant deciduous or coniferous tree species. However, the effect of forests is closely related to topographic characteristics (aspect and elevation) of a locality.

Key words: snow cover, snowpack properties, elevation gradient, Picea abies, Fagus sylvatica, water supply. 


\section{Introduction}

Snow cover represents an important phenomenon of water balance of forest ecosystems mainly in the mountainous areas, because in these parts, precipitation is temporarily accumulated in the solid state and, thus, transport of precipitation to soil environment is cut off (Mindáš, 2003). The current increasing pressure on hydrologic resources, their quality and availability increases the demands on the precision of estimation of winter water supply accumulated in snow cover. Previous works (Hríbik et al., 2009, 2012) found that winter precipitation fixed in snow cover in Hučava watershed represents from 15 to $40 \%$ of the total annual precipitation. On one side, snow cover is an important source of water for vegetation, but on the other side, it represents a potential risk of spring floods. Field monitoring of snowpack properties such as snow water equivalent (SWE) is one of the possibilities how to determine the water amount accumulated in snow cover (Danko et al., 2004). Forests and tree species composition of a watershed significantly affect the accumulation and duration of snow cover (Mindáš, 2003; Holko et al., 2009; Hríbik et al., 2012). Elder et al. (1991, 1998) and Jain et al. (2009) showed that snow accumulation and ablation is primarily controlled by atmospheric conditions, elevation and slope of the terrain. Important atmospheric processes affecting snow cover are precipitation, deposition, condensation, turbulent transfer of heat and moisture, radiative exchange and air movement. Land features influence snow accumulation by slope, aspect and shadowing properties. These factors act together and are related to each other (Luce et al., 1998; Jost et al., 2007).

The goal of this work was on the base of the measurements during three seasons in the Hučava river watershed situated in the Biosphere Reserve Polana:

- To compare the courses of the mean SWE values calculated for the whole watershed amongst the three winter seasons.

- To determine the average differences in mean seasonal SWE values between open areas and forest ecosystems dominated by Norway spruce and European beech.

- To identify and quantify the impact of aspect and elevation on the SWE in forest ecosystems and open areas of the watershed in accumulation and ablation periods of each winter season.

\section{Material and methods}

\section{Study area}

The research was performed in a small headwater watershed of the Hučavy flow $\left(41.2 \mathrm{~km}^{2}\right)$, which is situated in
the Polana Mts. (Slovakia, Central Europe, Inner Western Carpathians). The Polana Mts. is the highest volcanic
mountain range in Slovakia in which the elevation ranges from 460 to $1.458 \mathrm{~m}$ a.s.l. A large area of the examined
part of the watershed ( $94 \%$ ) belongs to the Polana Biosphere Reserve (BR) (Fig.1, part of UNESCO World Network
of Biosphere Reserves). According to the zonation of BR, $29.4 \%$ of the watershed is in the transition zone, $58.9 \%$ is
in the buffer zone and 5.7\% is in the core zone. The core zone encompasses all most important protection areas (left
to self-regulation processes), the buffer zone protects the core area against the surrounding influences (manage-
ment is subject to nature protection) and the management activity in the transition area should be in accordance
with the interests of nature and landscape protection. Forest cover of the watershed is $81.6 \%$ ( $33.6 \mathrm{~km}^{2}$ ), permanent
grassland cover $18.5 \%$ and arable land and settled area cover 0.2\%. Forest stands of the watershed occur in four for-
est elevation zones (beech - fourth forest elevation zone (FEZ); fir-beech - fifth FEZ; spruce-fir-beech - sixth FEZ; 
and spruce - seventh FEZ). The most common tree species is spruce (45.4\%) followed by beech (35.6\%), sycamore maple $(6.8 \%)$ and fir (5.0\%). Other tree species (predominantly broadleaved) make together 7.2\% (Kadlec, Kováŕ, 2008). Beech forests are predominant at southern aspects, whilst mixed forests with beech, fir and spruce prevail in the parts with the northern aspect. The natural tree species composition is more preserved at higher elevations, whilst at lower elevations, tree species composition has been substantially changed. The Polana Mts. were created by tertiary activities. It represents an eroded form of a volcano - stratovolcano. Its massif consists of Neogenic volcanic rocks, resistant andesites and rhyolites and softer volcanic clastic andesites in tuff and tuffite development (Dublan, Jánošová, 1991). Gömöryová et al. (2006) present that saturated and unsaturated Cambisols are the most common soil types. Andosols occur in the highest parts of the mountains. At one-third of the area, soils contain allophane, which causes high production of forest stands. From the climatological point of view, Polana watershed belongs to a slightly warm (slightly warm, very moist, upland district) and a cool climatic region (slightly cold and cold mountainous district). The average annual air temperature at the $\mathrm{BR}$ area fluctuates from 3 to $5{ }^{\circ} \mathrm{C}$. January and February are the coldest months, and July and August are the warmest months. Average annual precipitation totals are from 600 to $900 \mathrm{~mm}$, and they are $1,100 \mathrm{~mm}$ at the top of the Polana Mts. (1.458 m a.s.l.). On an average, snow cover is formed from the third decade of October and lasts until the end of April. In Polana, snow cover occurs on 130 days per year, on an average (Škvarenina, Mindášs, 2002).

\section{Snow survey}

For data collection, we used a classical, standard snow survey measurement technique (Anderton et al., 2002). It is based on the measurement of SWE along transects at regular intervals. In the watershed area of the river Hučava, 13 research plots (576-1.275 m a.s.l.) were established at elevation intervals of $100 \mathrm{~m}$ (7 plots in northern aspect and 6 plots in southern aspect; Fig. 1). At each research plot, we assessed SWE along three transects (Table 1). The first transect was located in a forest dominated by Norway spruce (Picea abies (L.) Karst.), the second in a forest dominated by European beech (Fagus sylvatica L.) and the third in an open area. The description of the research plots is presented in Table 1. In total, 39 transects were measured in the watershed. Ten SWE values were measured on each transect. A manual mass method (Durand, 2011) was used to measure the SWE. The measurements were performed during three winter seasons (from 2012-2013 to 2014-2015) in approximately biweekly intervals. The measured data were evaluated for the whole season or for the periods of the season (snow accumulation period, peak of snow accumulation and ablation period).
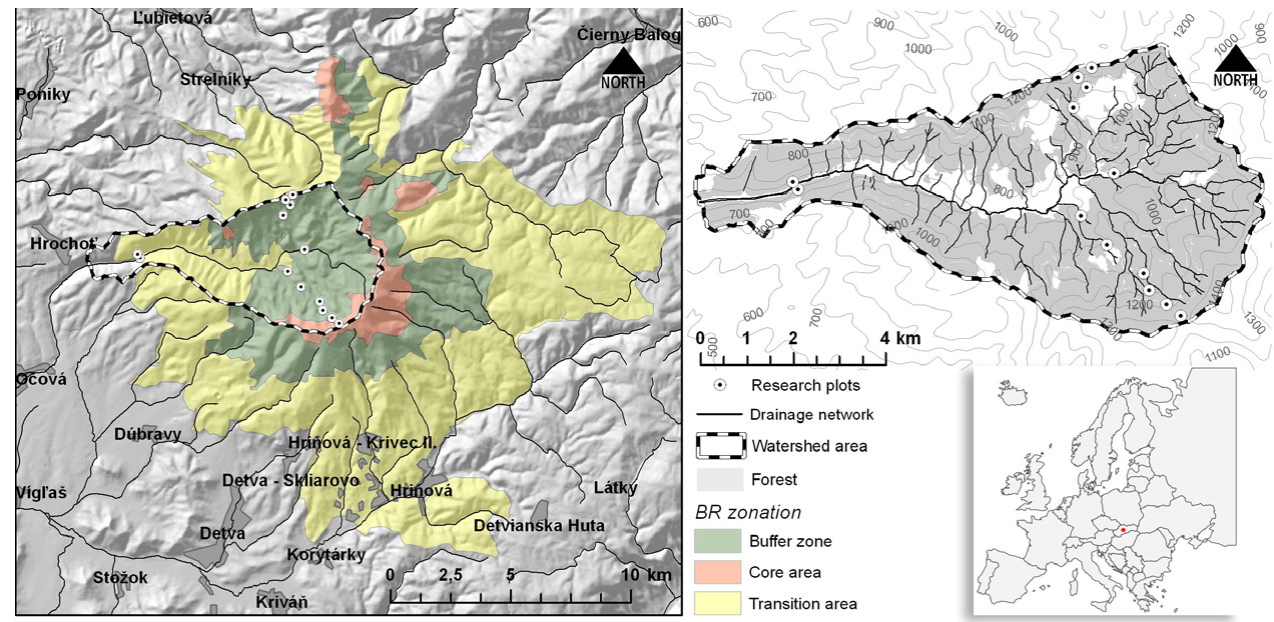

Fig. 1. Study site - upstream area of Hučava river watershed (Pol'ana Mts.) where 13 research plots were located. At each plot, we established a transect in an open area, in a forest dominated by Norway spruce, and in a forest dominated by European spruce. More than $81 \%$ of the watershed is covered by forests (upper right picture). The study site is located in Central Europe, Central Slovakia. 
$\mathrm{T}$ a b 1 e 1. Description of 13 research plots ( 7 with northern aspect and 6 with southern aspect). At each plot, SWE was measured on a transect situated in a forest dominated by Norway spruce (Ns), in a forest dominated by European beech $(\mathrm{Eb})$ and in an open area $(\mathrm{Oa})$.

\begin{tabular}{|c|c|c|c|c|c|c|c|}
\hline \multicolumn{4}{|c|}{ Northern aspect } & \multicolumn{4}{|c|}{ Southern aspect } \\
\hline $\begin{array}{l}\text { Elevation } \\
\text { (m a.s.l.) }\end{array}$ & Transect & Age class & $\begin{array}{c}\text { Stand } \\
\text { density }\end{array}$ & $\begin{array}{l}\text { Elevation } \\
(\mathrm{m} \text { a.s.l. })\end{array}$ & Transect & Age class & $\begin{array}{c}\text { Stand } \\
\text { density }\end{array}$ \\
\hline 578 & Ns & $41-60$ & 1.0 & 604 & Ns & $41-60$ & 0.8 \\
\hline 578 & $\mathrm{~Eb}$ & $21-40$ & 0.9 & 567 & $\mathrm{~Eb}$ & $41-60$ & 1.0 \\
\hline 576 & $\mathrm{Oa}$ & & & 601 & $\mathrm{Oa}$ & & \\
\hline 809 & Ns & $41-60$ & 0.8 & 835 & Ns & $41-60$ & 0.8 \\
\hline 805 & $\mathrm{~Eb}$ & $41-60$ & 0.8 & 830 & $\mathrm{~Eb}$ & $61-80$ & 0.8 \\
\hline 804 & $\mathrm{Oa}$ & & & 833 & $\mathrm{Oa}$ & & \\
\hline 897 & Ns & $41-60$ & 1.0 & 915 & Ns & $41-60$ & 0.8 \\
\hline 900 & $\mathrm{~Eb}$ & $61-80$ & 0.8 & 918 & $\mathrm{~Eb}$ & $61-80$ & 0.8 \\
\hline 899 & $\mathrm{Oa}$ & & & 920 & $\mathrm{Oa}$ & & \\
\hline 1.003 & Ns & $61-80$ & 0.8 & 1.001 & Ns & $81-100$ & 0.9 \\
\hline 1.003 & $\mathrm{~Eb}$ & $61-80$ & 0.9 & 1.007 & $\mathrm{~Eb}$ & $81-100$ & 0.9 \\
\hline 1.004 & $\mathrm{Oa}$ & & & 1.001 & $\mathrm{Oa}$ & & \\
\hline 1.059 & Ns & $81-100$ & 1.0 & 1.082 & Ns & $101-120$ & 0.8 \\
\hline 1.076 & $\mathrm{~Eb}$ & $61-80$ & 0.9 & 1.074 & $\mathrm{~Eb}$ & $120+$ & 0.7 \\
\hline 1.066 & $\mathrm{Oa}$ & & & 1.095 & $\mathrm{Oa}$ & & \\
\hline 1.179 & Ns & $120+$ & 0.8 & 1.160 & Ns & $101-120$ & 0.8 \\
\hline 1.167 & $\mathrm{~Eb}$ & $120+$ & 0.8 & 1.159 & $\mathrm{~Eb}$ & $120+$ & 0.7 \\
\hline 1.174 & $\mathrm{Oa}$ & & & 1.175 & $\mathrm{Oa}$ & & \\
\hline 1.259 & Ns & $120+$ & 0.7 & & & & \\
\hline 1.239 & Beech & $120+$ & 0.8 & & & & \\
\hline 1.275 & $\mathrm{Oa}$ & & & & & & \\
\hline
\end{tabular}

\section{Data analysis}

A paired t-test was used for the statistical comparison of the paired samples (measurements) to determine whether the mean of the differences between the two paired samples differed from zero. Prior to the comparison, the paired zero values were excluded from the samples. As the p-value for this test was less than 0.05 , we could reject the null hypothesis at $95 \%$ confidence level. Each mean value is presented with its standard error (mean \pm SE). The relationship between the dependent and independent variables was tested by a simple linear regression. Statistical significance of the linear relationship was tested with analysis of variance at $95 \%$ significance level. If p-value was equal to or greater than 0.05 , the relationship was not significant. The strength of the linear statistical relationship is quantified by the value of Pearson correlation coefficient (r). Elevation gradients of SWE were deduced from the linear models as their regression coefficients. Linear models (SWE vs. time) were also used to calculate the ablation rate values. All analyses were performed using Statgraphics Centurion XVI software (Version 16.1.11).

\section{Results}

SWE measurements were performed during the three winter seasons (from 2012-2013 to 2014-2015). Each season was divided into a period of snow accumulation, a period with the first $(1.3 .13,16.12 .13,11.2 .15)$ and the second peaks $(2.4 .13,31.1 .14,9.4 .15)$ and a snow 
ablation period (Fig. 2). For the statistical analyses, we used one peak for each season as an average of the first and second peaks.

The studied winter seasons were highly variable in SWE (Fig. 2). According to our monitoring, the duration of snow cover in the snow-rich winter of 2012-2013 was 145 days and the whole watershed mean peak SWE value was $157.7 \pm 11.2 \mathrm{~mm}$. The duration of the snow cover in the winter 2014-2015 was 82 days and the mean peak SWE value was $69.3 \pm 5.2 \mathrm{~mm}$. In the snow poorest winter of 2013-2014, the snow cover lasted only 46 days and the mean peak SWE value was $13.5 \pm 1.7 \mathrm{~mm}$. In that winter season, the duration of snow cover was more than three months shorter and the value of the mean peak SWE was lower by about 144 $\mathrm{mm}$ (91.4\%) compared to the season 2012-2013. The three-season, whole watershed peak SWE value was $80.2 \pm 5.7 \mathrm{~mm}$ (Fig. 2).

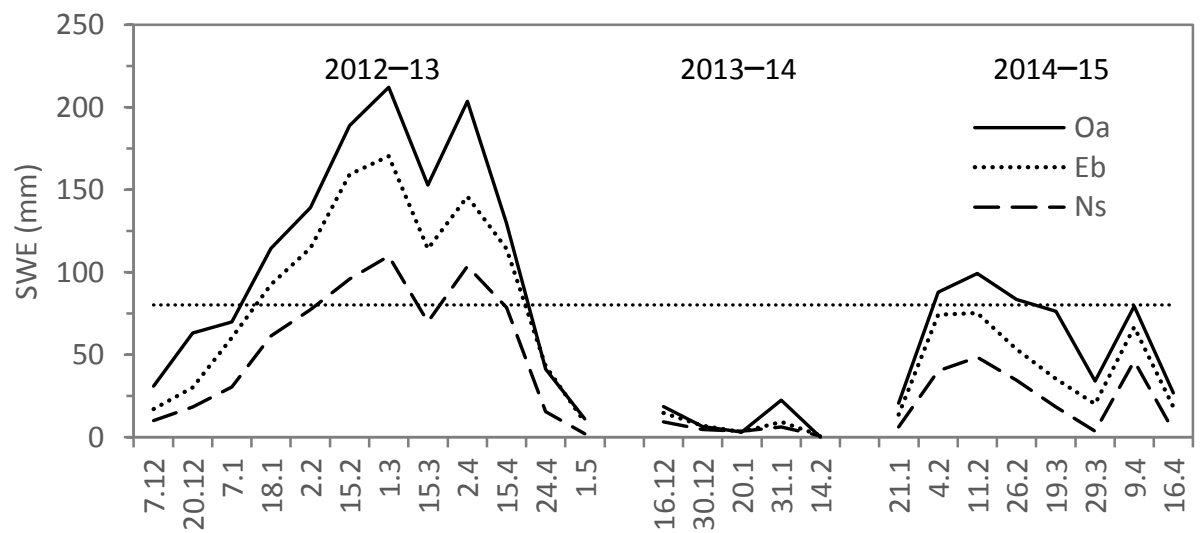

Fig. 2. Temporal development of the whole watershed mean SWE in the open areas (Oa) and the forest stands dominated by Norway spruce (Ns) or European beech (Eb). The horizontal line indicates the three-season, whole watershed peak SWE value.

\section{Effect of forests}

Forest ecosystems significantly decreased SWE on the ground in the winters 2012-2013 and 2014-2015 (Table 2). In the season 2013-2014, total solid precipitation was too low to prove the significant effect of forests. The difference in seasonal, whole watershed mean SWE values was evident mainly between the open areas $(\mathrm{Oa})$ and the forests dominated by Norway spruce (Ns) than between forests dominated by European beech (Eb). If we take $\mathrm{Oa}$ as a reference plot (100\%), the seasonal mean SWE value in Ns and Eb was lower, on an average, by $50-60 \%$ and $21-30 \%$, respectively, in every of the monitored seasons (Fig. 2, Table 2). The greatest whole-season difference between $\mathrm{Oa}$ and $\mathrm{Ns}$ equal to $57.1 \pm 9.1 \mathrm{~mm}$ was recorded in the winter 2012-2013 (Table 2a). 
$\mathrm{T}$ a b 1 e 2. Differences between the seasonal mean SWE values (whole watershed values) in the open areas of the whole watershed area and the forests dominated by (a) Norway spruce (Ns) and (b) European beech (Eb). The calculation of the relative difference assumes that $\mathrm{Oa}$ is $100 \%$ (reference plot). The paired t-test compared data set of mean SWE values in watershed. Asterisk $\left(^{*}\right)$ indicates significant difference at $\mathrm{p}<0.05$.

\begin{tabular}{|c|c|c|c|c|c|c|}
\hline \multirow{2}{*}{ (a) Oa vs. Ns } & \multicolumn{2}{|c|}{ Mean SWE \pm SE } & \multicolumn{2}{|c|}{ Difference (Oa - Ns) } & \multirow{2}{*}{$\begin{array}{c}\text { p-value } \\
\text { paired t-test }\end{array}$} & \multirow{2}{*}{$\mathbf{n}$} \\
\hline & Oa & Ns & Mean \pm SE & Percentage & & \\
\hline $2012-2013$ & $113.2 \pm 20.0$ & $56.1 \pm 11.2$ & $57.1 \pm 9.1$ & 50.4 & $6.3 \cdot 10^{-5 \star}$ & 12 \\
\hline $2013-2014$ & $10.2 \pm 4.4$ & $5.0 \pm 1.4$ & $5.2 \pm 3.3$ & 51.1 & 0.191 & 5 \\
\hline $2014-2015$ & $63.6 \pm 11.0$ & $25.3 \pm 6.8$ & $38.3 \pm 5.4$ & 60.2 & $1.9 \cdot 10^{-4 \star}$ & 8 \\
\hline
\end{tabular}

\begin{tabular}{|c|c|c|c|c|c|c|}
\hline \multirow{2}{*}{ (b) Oa vs. Eb } & \multicolumn{2}{|c|}{ Mean SWE \pm SE } & \multicolumn{2}{|c|}{ Difference (Oa - Ns) } & \multirow{2}{*}{$\begin{array}{c}\text { p-value } \\
\text { paired t-test }\end{array}$} & \multirow{2}{*}{$\mathbf{n}$} \\
\hline & Oa & $\mathbf{E b}$ & Mean \pm SE & Percentage & & \\
\hline $2012-2013$ & $113.2 \pm 20.0$ & $89.4 \pm 16.2$ & $23.8 \pm 5.0$ & 21.0 & $6.1 \cdot 10^{-4 \star}$ & 12 \\
\hline $2013-2014$ & $10.2 \pm 4.4$ & $7.1 \pm 2.4$ & $3.1 \pm 2.7$ & 30.4 & 0.309 & 5 \\
\hline $2014-2015$ & $63.6 \pm 11.0$ & $44.7 \pm 9.2$ & $18.9 \pm 4.2$ & 29.7 & 0.003 & 8 \\
\hline
\end{tabular}

\section{Impact of aspect}

Aspect has a significant impact on the SWE values in the watershed. Mean SWE in Ns, Eb and Oa was usually higher on the slopes with northern aspect than on those with southern aspect (Fig. 3, valid for 2012-2013 and 2014-2015 seasons). The exceptions were only five dates in the ablation period in the forest ecosystems dominated by Norway spruce (Fig. 4). This phenomenon was most probably caused by the micro-climate of the specific spruce stands with high canopy cover. In the season 2013-2014, total solid precipitation was too low to see and confirm the significant effect of aspect. The paired comparison of mean SWE values (a paired t-test) of 13 research plots with northern and southern aspects showed the highest statistical differences in the open areas and in the forests dominated by European beech (Table 3).
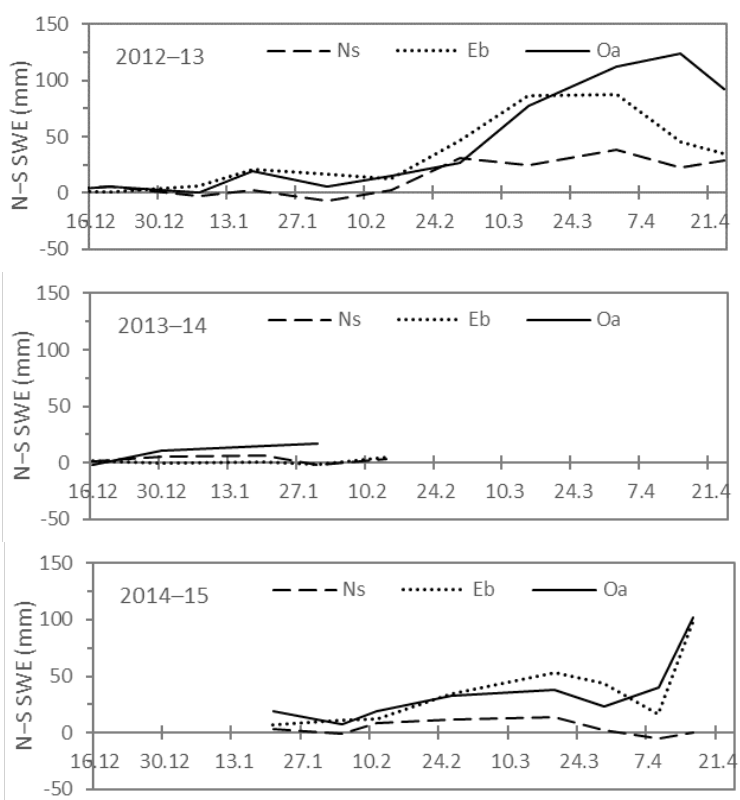

Fig. 3. Visualisation of differences between mean SWE at northern and southern slopes of the watershed in open areas (Oa) and the forests dominated by Norway spruce (Ns) and European beech (Eb) in three seasons. N-S SWE mean values represent the results of the subtraction between the paired mean SWE values measured at the research plots with the northern and southern aspects. We excluded zero-paired values of SWE from the subtraction. If N-S SWE value was negative at a particular date, the SWE value on southern slopes was greater, on an average. 


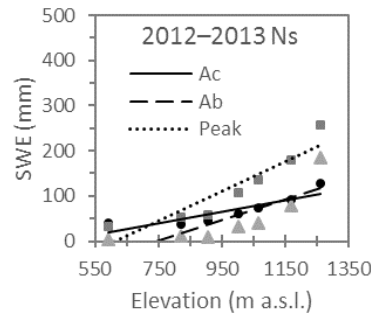

Ac: $y=0.130 x-58.668 ; r=0.885 ; p=$ $\underline{0.008}$

Peak: $y=0.328 x-202.283 ; r=0.921$; $\mathrm{p}=0.003$

Ab: $y=0.227 x-169.309 ; r=0.795 ; \underline{p}$ $=0.0325$

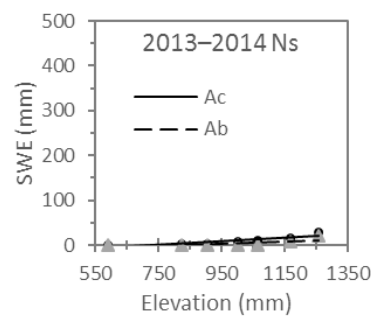

Ac: $y=0.039 x-28.813 ; r=0.884 ; p=$ $\underline{0.008}$

Ab: $y=0.025 x-20.335 ; r=0.710 ; p=$ 0.074

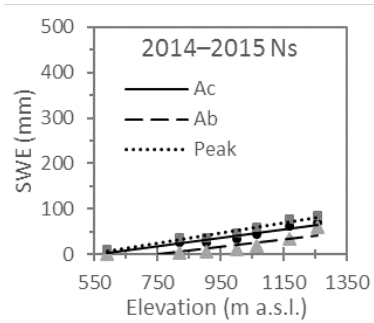

Ac: $y=0.092 x-52.056 ; r=0.968 ; p=$ 4.0.10exp-4

Peak: $y=0.113 x-59.495 ; r=0.978 ; \underline{p}$ $=1.0 \cdot 10$ exp -4

Ab: $y=0.079 x-58.425 ; r=0.850 ; p=$ 0.015

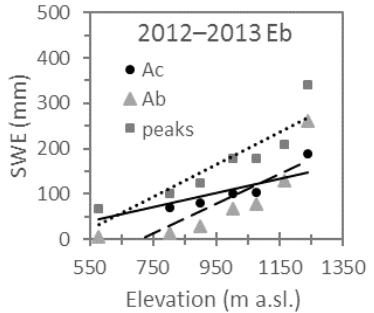

Ac: $y=0.155 x-44.529 ; r=0.839 ; p=$ $\underline{0.018}$

Peaks: $y=0.356 x-172.416 ; r=0.896$; $\mathrm{p}=0.006$

Ab: $y=0.328 x-232.929 ; r=0.834 ; p$ $=0.020$

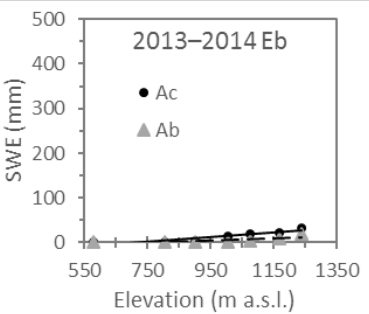

Ac: $y=0.050 x-34.652 ; r=0.925 ; p=$ $\underline{0.003}$

Ab: $y=0.025 x-18.833 ; r=0.781 ; p=$ $\underline{0.038}$

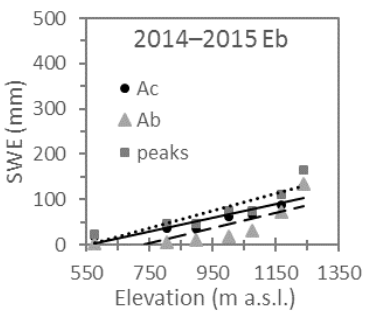

Ac: $y=0.151 x-83.390 ; r=0.917 ; p=$ $\underline{0.004}$

Peaks: $y=0.190 x-105.646 ; r=0.899$; $\mathrm{p}=0.006$

Ab: $y=0.167 x-122.537 ; r=0.798 ; p$ $=0.032$

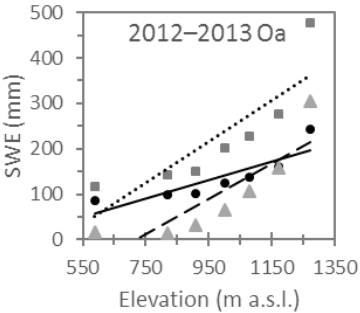

Ac: $y=0.202 x-61.671 ; r=0.870 ; p=$

$\underline{0.011}$

Peaks: $y=0.455 x-217.945 ; r=$

$0.849 ; \mathrm{p}=0.016$

Ab: $y=0.387 x-279.485 ; r=0.851 ; p$ $\underline{=0.015}$

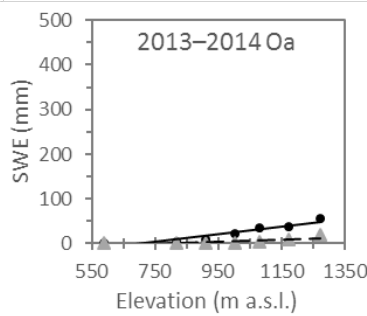

Ac: $y=0.083 x-58.513 ; r=0.939 ; p=$ $\underline{0.002}$

Ab: $y=0.023 x-18.557 ; r=0.775 ; p=$ $\underline{0.041}$

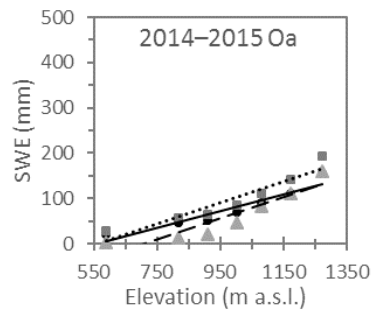

Ac: $y=0.184 x-102.026 ; r=0.952 ; \underline{p}$ $=0.001$

Peaks: $y=0.233 x-130.813 ; r=0.947$; $\mathrm{p}=0.001$

Ab: $y=0.230 x-162.164 ; r=0.921 ; p$ $=0.003$

Fig. 4. Correlation (simple linear regression) between mean SWE and elevation in the forest stands dominated by Norway spruce (Ns) and European beech $(\mathrm{Eb})$ and in the open areas $(\mathrm{Oa})$ in three winter seasons. Each winter season was split into the period of snow accumulation (Ac), snow ablation (Ab) and peak of season (Peak). Every dot represents a mean SWE value of the research plots with the northern and southern aspects. If $y=b x+a$ (equation of the linear model), then $\mathrm{b}$ (regression coefficient) is a modelled value of elevation gradient per $1 \mathrm{~m}$ of elevation. The strength of the linear relationship is expressed by the value of the Pearson correlation coefficient - r $(1-$ strongest, 0 - no correlation), and the significance of the relationship is indicated by p-value (p-value is underlined if the relationship is statistically significant). In the season 2013-2014, the accumulation period was equal to the peak. 
T a b le 3. Mean SWE values on the northern and southern slopes of the watershed in the period of snow accumulation, peak of snow accumulation and ablation period. The zero-paired values were excluded from the calculation of the mean difference $(\mathrm{N}-\mathrm{S})$ between SWE measured at the northern and the southern research plots. The calculation of the relative difference assumes that the value for the northern aspect is $100 \%$.

\begin{tabular}{|c|c|c|c|c|c|c|c|}
\hline \multicolumn{2}{|c|}{ 2012-2013 } & \multicolumn{2}{|c|}{ Mean SWE \pm SE } & \multicolumn{2}{|c|}{ Difference $(\mathrm{N}-\mathrm{S})$} & \multirow{3}{*}{$\begin{array}{c}\begin{array}{c}\text { p-value } \\
\text { paired t-test }\end{array} \\
0.013^{*} \\
\end{array}$} & \multirow{3}{*}{$\begin{array}{c}\mathbf{n} \\
48\end{array}$} \\
\hline & & \multirow{2}{*}{$\frac{\mathrm{N}}{62.6 \pm 7.4}$} & \multirow{2}{*}{$\begin{array}{c}\text { S } \\
53.5 \pm 5.9\end{array}$} & \multirow{2}{*}{$\begin{array}{c}\text { Mean } \pm \text { SE } \\
9.1 \pm 3.5\end{array}$} & \multirow{2}{*}{$\begin{array}{c}\text { Percentage } \\
14.6\end{array}$} & & \\
\hline \multirow{3}{*}{ Ns } & Accumulation period & & & & & & \\
\hline & Peak & $111.7 \pm 18.1$ & $76.9 \pm 15.0$ & $34.7 \pm 9.3$ & 31.1 & $\mathbf{0 . 0 0 3}^{*}$ & 12 \\
\hline & Ablation period & $66.7 \pm 15.8$ & $42.6 \pm 11.9$ & $24.1 \pm 6.3$ & 36.1 & $0.002^{*}$ & 13 \\
\hline \multirow{3}{*}{$\mathrm{Eb}$} & Accumulation period & $103.6 \pm 10.1$ & $79.3 \pm 7.6$ & $24.3 \pm 5.2$ & 23.5 & $2.3 \cdot 10^{-5 *}$ & 48 \\
\hline & Peak & $176.4 \pm 17.1$ & $109.5 \pm 16.7$ & $66.9 \pm 12.2$ & 37.9 & $1.9 \cdot 10^{-4 *}$ & 12 \\
\hline & Ablation period & $123.5 \pm 22.3$ & $62.8 \pm 17.6$ & $60.7 \pm 10.0$ & 49.1 & $3.9 \cdot 10^{-5 *}$ & 14 \\
\hline \multirow{3}{*}{$\mathrm{Oa}$} & Accumulation period & $130.1 \pm 12.0$ & $106.6 \pm 8.3$ & $23.6 \pm 6.2$ & 18.1 & $4.0 \cdot 10^{-4 \star}$ & 48 \\
\hline & Peak & $220.2 \pm 23.3$ & $150.7 \pm 15.4$ & $69.6 \pm 18.2$ & 31.6 & $0.003^{\star}$ & 12 \\
\hline & Ablation period & $157.9 \pm 27.7$ & $66.1 \pm 23.6$ & $91.8 \pm 19.5$ & 58.1 & $4.0 \cdot 10^{-4 \star}$ & 14 \\
\hline
\end{tabular}

\begin{tabular}{|c|c|c|c|c|c|c|c|}
\hline \multirow{2}{*}{\multicolumn{2}{|c|}{ 2013-2014 }} & \multicolumn{2}{|c|}{ Mean $\pm S E$} & \multicolumn{2}{|c|}{ Difference $(\mathrm{N}-\mathrm{-S})$} & \multirow{3}{*}{$\begin{array}{c}\begin{array}{c}\text { p-value } \\
\text { paired t-test }\end{array} \\
0.292\end{array}$} & \multirow[b]{3}{*}{8} \\
\hline & & \multirow{2}{*}{$\begin{array}{c}\mathbf{N} \\
9.0 \pm 0.6\end{array}$} & \multirow{2}{*}{$\begin{array}{c}\mathbf{S} \\
9.7 \pm 0.6\end{array}$} & \multirow{2}{*}{$\begin{array}{c}\text { Mean } \pm \text { SE } \\
-0.7 \pm 0.2\end{array}$} & \multirow{2}{*}{$\begin{array}{c}\text { Percentage } \\
-8.1\end{array}$} & & \\
\hline $\mathrm{Ns}$ & Accumulation period & & & & & & \\
\hline NS & Ablation period & $7.9 \pm 2.4$ & $2.9 \pm 1.9$ & $5.0 \pm 0.6$ & 62.9 & $0.001^{\star}$ & 5 \\
\hline \multirow{2}{*}{$\mathrm{Eb}$} & Accumulation period & $15.3 \pm 1.1$ & $15.9 \pm 0.9$ & $-0.6 \pm 0.3$ & -4.0 & 0.573 & 8 \\
\hline & Ablation period & $8.0 \pm 3.0$ & $7.0 \pm 2.0$ & $1.0 \pm 2.0$ & 11.9 & 0.658 & 6 \\
\hline \multirow{2}{*}{$\mathrm{Oa}$} & Accumulation period & $27.8 \pm 6.1$ & $19.4 \pm 3.9$ & $8.4 \pm 4.7$ & 30.2 & 0.113 & 9 \\
\hline & Ablation period & $17.9 \pm 4.0$ & $6.1 \pm 3.1$ & $11.9 \pm 3.6$ & 66.2 & 0.082 & 3 \\
\hline
\end{tabular}

\begin{tabular}{|c|c|c|c|c|c|c|c|}
\hline \multirow{2}{*}{\multicolumn{2}{|c|}{ 2014-2015 }} & \multicolumn{2}{|c|}{ Mean \pm SE } & \multicolumn{2}{|c|}{ Difference $(\mathbf{N}-\mathrm{S})$} & \multirow{3}{*}{$\begin{array}{c}\begin{array}{c}\text { p-value } \\
\text { paired t-test }\end{array} \\
0.763\end{array}$} & \multirow{3}{*}{$\begin{array}{l}\mathbf{n} \\
20 \\
\end{array}$} \\
\hline & & \multirow{2}{*}{$\frac{\mathrm{N}}{39.5 \pm 4.8}$} & \multirow{2}{*}{$\begin{array}{c}\mathbf{S} \\
38.6 \pm 5.5\end{array}$} & \multirow{2}{*}{$\begin{array}{c}\text { Mean } \pm \text { SE } \\
0.9 \pm 3.0\end{array}$} & \multirow{2}{*}{$\begin{array}{c}\text { Percentage } \\
2.3\end{array}$} & & \\
\hline \multirow{3}{*}{ Ns } & Accumulation period & & & & & & \\
\hline & Peak & $45.1 \pm 5.8$ & $43.4 \pm 7.8$ & $1.7 \pm 4.7$ & 3.7 & 0.730 & 12 \\
\hline & Ablation period & $33.7 \pm 7.1$ & $22.4 \pm 7.6$ & $11.4 \pm 2.4$ & 33.8 & $0.001^{\star}$ & 10 \\
\hline \multirow{3}{*}{$\mathrm{Eb}$} & Accumulation period & $59.7 \pm 8.2$ & $48.0 \pm 6.8$ & $11.7 \pm 3.3$ & 19.6 & $0.002^{\star}$ & 23 \\
\hline & Peak & $70.1 \pm 10.8$ & $56.0 \pm 8.0$ & $14.1 \pm 5.9$ & 20.1 & $0.036^{*}$ & 12 \\
\hline & Ablation period & $64.0 \pm 11.6$ & $21.7 \pm 6.6$ & $42.4 \pm 7.8$ & 66.2 & $2.1 \cdot 10^{-4 \star}$ & 12 \\
\hline \multirow{3}{*}{$\mathrm{Oa}$} & Accumulation period & $78.7 \pm 10.2$ & $57.1 \pm 8.4$ & $21.5 \pm 4.9$ & 27.4 & $2.4 \cdot 10^{-4 \star}$ & 23 \\
\hline & Peak & $95.5 \pm 15.0$ & $65.9 \pm 10.7$ & $29.6 \pm 8.4$ & 31.0 & $4.9 \cdot 10^{-3 *}$ & 12 \\
\hline & Ablation period & $90.4 \pm 9.9$ & $49.4 \pm 14.1$ & $41.0 \pm 8.3$ & 45.3 & $1.9 \cdot 10^{-4 \star}$ & 16 \\
\hline
\end{tabular}

The statistical results revealed the weakest impact of aspect in the forests dominated by Norway spruce.

In each season, the percentage difference between the mean SWE on the northern and the southern slopes increased starting from the accumulation period through the peak of snow accumulation up to the ablation period when the difference was greatest (Table 3 ). The values of the differences followed the same trend. The greatest average differences between the northern and southern aspects were recorded in the open areas of the watershed to the end of the winter sea- 
sons (Fig. 3). The mean SWE values calculated from the measurements on the north facing slopes were considered as the reference values (100\%). The mean SWE (in the ablation period) in the $\mathrm{Oa}$ at the southern slopes was lower by $36-66 \%$ compared to the northern slopes; the differences were from 12 to $66 \%$ lower in the Eb and from 34 to $63 \%$ lower in the Ns (Table 3, three-season variability).

\section{Impact of elevation}

Elevation affects SWE. SWE increased with the increasing elevation in all three seasons in the accumulation and ablation periods and also in the peak of the winter seasons (Fig. 4). The highest SWE values were recorded at the research plots situated at the highest elevations. The relationship between SWE and elevation was described using linear models, whilst their correlation coefficients indicated relatively strong relationships between the variables. In the ablation period, the strength of the relationship was the lowest. The relationship was significant (if p-value is $<0.05$ ) in all three seasons in the period of snow accumulation with the peak of the season and in the ablation period of snow cover. The statistical significance was not proved only in the poor snow season 2013-2014, in the ablation period of the forest dominated by Ns. In that period, there was so little snow in the forest that the generally strong relationship between SWE and elevation was not significant.

The equation of the linear regression model is $y=b x+a$. In our case, $b$ (regression coefficient) indicated a modelled value of elevation gradient of SWE per $1 \mathrm{~m}$ of elevation. The increasing mean SWE value with the elevation was obvious in all three seasons (Fig. 4). The lowest value of gradient was always found in the ecosystems dominated by Ns, and the highest value was always in the open areas of the watershed, whilst the gradient of the ecosystem dominated by Eb was in between. The three-season mean value of SWE elevation gradient (per $100 \mathrm{~m}$ ) in the peaks of the seasons was $16 \mathrm{~mm}$ in Ns, $20 \mathrm{~mm}$ in $\mathrm{Eb}$ and $26 \mathrm{~mm}$ in Oa. The greatest gradient value of $46 \mathrm{~mm}$ per $100 \mathrm{~m}$ of elevation was found in $\mathrm{Oa}$ in the peak of the snow-rich season 2012-2013. As the value of the elevation gradient increases, the spatial variability of SWE in the watershed also increases. The greatest variability of mean SWE values at the research plots was found in the snow-rich season 2012-2013.

\section{Discussion}

Snow cover duration, depth and water equivalent (SWE) are the three major snow cover characteristics (Bulygina et al., 2009). SWE represents the amount of water that will be available for the surrounding watershed environment during spring melt (Durand, 2011). SWE has a great interannual variability at a large scale of the Northern hemisphere (Brown, 2000; Peng et al., 2013) but in Europe also at local scales of the Pyrenees (Lopez-Moreno, Vicente-Serrano, 2007), the Alps (Beniston, 1997; López-Moreno et al., 2015) and the Carpathians (Hríbik et al., 2009). We confirmed large three-season inter-annual variability in snow cover duration and mean peak SWE in the mountains of the Inner Western Carpathians. The comparison of the snow richest and poorest winter seasons showed the difference in their snow cover duration of more than three months and $91.4 \%$ difference in the mean peak SWE. 
The spatial-temporal variability of snow cover characteristics has a significant effect on local ecology (Litaor et al., 2008) and hydrology (Balk, Elder, 2000; Lundquist, Dettinger, 2005; Bavay et al., 2013). At the watershed scale, the variability of SWE is mainly influenced by topography, elevation, aspect (Anderton et al., 2004) and vegetation (Winkler et al., 2005). Forest cover decreases SWE and snow melt rate compared to open areas by changing the snowpack energy balance (Essery et al., 2008) and interception (Bartík et al., 2014). We found significantly lower means and seasonal SWE values in the forests compared to the open areas. The difference was evident mainly between the open areas and the forest dominated by Norway spruce (Ns) (50-60\%, on an average), and it was less evident for the forest dominated by European beech (Eb) (21-30\%, on an average). Kuz'min (1960) revealed similar results, as he found that the mean peak SWE in spruce forests is 10-60\% lower than that in open areas. Other studies (Hedstrom, Pomeroy, 1998; Pomeroy et al., 1998) showed that $40-60 \%$ of the total annual snowfall can be intercepted by coniferous forest cover. Generally, SWE on the ground decreases with the increasing leaf area and canopy density during the winter season (Pomeroy et al., 2002).

Topography strongly influences snow distribution (Grünewald et al., 2013). The effect of aspect on snow accumulation and ablation depends on the exposure to solar radiation. Higher SWE values are expected on slopes with northern aspects (in the northern hemisphere) because of the reduced melting and sublimation rates (Golding, Swanson, 1986). Our results showed a general tendency of higher SWE values on north-facing slopes compared to south-facing slopes. This tendency was more obvious in the open areas and the forests dominated by Eb than in Ns forest. The probable reason is that the high spruce canopy cover protects the snowpack from incoming solar radiation, resulting in lower melting rate (Pomeroy et al., 2002; Talbot et al., 2006). The percentage difference in SWE between the north and south was the lowest in the accumulation period after which it was increasing and reached its maximum in the ablation period. The difference in the ablation period varied from 12 to 66\%. D'Eon (2004) and Jost et al. (2007) revealed that less snow was accumulated on the southern compared to northern aspects in different elevation ranges.

Precipitation usually increases with elevation (Roe, Baker, 2006; Liu et al., 2011). The magnitude of snowfall also increases with the increasing elevation resulting in the increase of snow depth and SWE (Lopez-Moreno, Stähli, 2008; Grünewald, Lehning, 2011). We confirmed strong positive relationships of SWE with elevation in all three seasons in the accumulation, ablation period and also the peak of the winter seasons. The statistical significance was not proved only in the snow poor season but also in the ablation period of the forest dominated by Ns. The reason was high canopy interception of the coniferous spruce forest ecosystem resulting in significantly decreased SWE. The values of the elevation gradient were always lowest in the ecosystems dominated by Ns, whilst in the ecosystems dominated by Eb, the gradients were higher and the highest values were found at the open areas of the watershed. The three-season mean value of SWE elevation gradient (per $100 \mathrm{~m}$ ) in the peaks of the seasons was $16 \mathrm{~mm}$ in Ns, $20 \mathrm{~mm}$ in Eb and $26 \mathrm{~mm}$ in Oa. Toews and Gluns (1986) found out the increase of 11-15 $\mathrm{mm}$ of SWE per $100 \mathrm{~m}$ in forested sites and 21-27 mm for open sites along elevation gradients. Kirchner et al. (2014) also found a positive elevation gradient, although with a sharp decrease in the highest elevations. A similar pattern was identified by Holko (2000) in Slovakia (Nízke Tatry Mts.) where it was explained by the wind exposure of the summit zone. Wind redistributes snow from the top of the hills (Trujillo et al., 2007; Lehning et al., 2008). We cannot confirm this pattern in the Polana Mts. (Slovakia) be- 
cause of the absence of the zone above the upper tree line where wind plays a major role for snow deposition and redistribution. Hence, on the contrary, we always found the highest SWE values at the research plots situated at highest elevations both in open areas and in forest ecosystems.

\section{Conclusion}

The three winter seasons from 2012-2013 to 2014-2015 were highly variable in the snow cover duration and the mean peak SWE. In the snow poorest season 2013-2014, the duration of snow cover was more than three weeks shorter and the mean peak SWE was lower by about $91.4 \%$ compared to the snow-rich season 2012-2013. Forest ecosystems at the watershed scale significantly decreased the SWE over the seasons. The mean seasonal SWE value was lower by $50-60 \%$ in the spruce forest and by $21-30 \%$ in the beech forest compared to the open areas (100\%). The topography of the watershed plays also an important role in the spatial distribution of SWE. On the north-facing slopes, the SWE was normally higher compared to the south-facing slopes. The impact of aspect increases from the accumulation period through the peak of snow accumulation up to the ablation period when the difference was greatest. The difference between the north- and south-facing slopes varied from 12 to $66 \%$ in the ablation period. In the spruce forest, the difference was significantly lower than that in the beech forest and the open areas of the watershed. Elevation is another factor of the watershed topography. We found strong positive relationship between SWE and elevation. SWE increased with elevation to the upper zone where it reached its maximum. The three-season mean value of SWE elevation gradient (per $100 \mathrm{~m}$ ) was in the peaks of the seasons and was equal to $16 \mathrm{~mm}$ in the spruce forest, $20 \mathrm{~mm}$ in the beech forest and $26 \mathrm{~mm}$ in Oa. The value of the elevation gradient decreased due to the high canopy cover of the spruce forest and in the snow-poor winter season. From the research results, we can conclude that the forest ecosystems significantly decrease the SWE but their impacts depend on the dominance of deciduous or coniferous tree species. In addition, the effect of forests depends also on the topographic characteristics (aspect and elevation) of a watershed. We can conclude that in the forested mountainous watershed, there is a lower risk of spring flooding from snow melt because of the evident decrease in SWE on the ground under the forest canopy. Hence, the highly forested Biosphere Reserve Polana is protected against the extreme flooding events originating from snow melting.

\section{Acknowledgements}

This work was accomplished as a part of VEGA project No. 1/0589/15 and 1/0570/16 of the Ministry of Education, Science, Research and Sport of the Slovak Republic and the Slovak Academy of Science and the projects of the Slovak Research and Development Agency No. APVV-15-0425 and APVV-15-0497. The authors thank the agencies for the support.

\section{References}

Anderton, S.P., White, S.M. \& Alvera B. (2002). Micro-scale spatial variability and the timing of snow melt runoff in a high mountain catchment. J. Hydrol., 268, 158-176. DOI: 10.1016/S0022-1694(02)00179-8.

Anderton, S.P., White, S.M. \& Alvera B. (2004). Evaluation of spatial variability in snow water equivalent for a high mountain catchment. Hydrological Processes, 18, 435-453. DOI: 10.1002/Hyp.1319.

Bartík, M., Sitko, R., Oreňák, M., Slovik, J. \& Škvarenina J. (2014). Snow accumulation and ablation in disturbed moun- 
tain spruce forest in West Tatra Mts. Biologia, 69, 1492-1501. DOI: 10.2478/s11756-014-0461-x.

Balk, B. \& Elder K. (2000). Combining binary decision tree and geostatistical methods to estimate snow distribution in a mountain watershed. Water Resources Research, 36, 13-26. DOI: 10.1029/1999wr900251.

Bavay, M., Grünewald, T. \& Lehning M. (2013). Response of snow cover and runoff to climate change in high Alpine catchments of Eastern Switzerland. Advances in Water Resources, 55, 4-16. DOI: 10.1016/j.advwatres.2012.12.009.

Beniston, M. (1997). Variations of snow depth and duration in the Swiss Alps over the last 50 years: links to changes in large-scale climatic forcings. Climatic Change at High Elevation Sites, 36, 281-300. DOI: 10.1023/A:1005310214361.

Brown, R.D. (2000). Northern hemisphere snow cover variability and change, 1915-1997. Journal of Climate, 13, 23392355. DOI: $10.1175 / 15200442(2000) 013<2339$ :NHSCVA $>2.0 . C O ; 2$.

Bulygina, O.N., Razuvaev, V.N. \& Korshunova N. N. (2009). Changes in snow cover over Northern Eurasia in the last few decades. Environmental Research Letters, 4, 1-6. DOI: 10.1088/1748-9326/4/4/045026.

Danko, M., Krajčí, P. \& Hlavčo J. (2014). The relationship between snow depth and snow water equivalent in the forest and in the open area in the Jalovecký creek catchment (in Slovak). Acta Hydrologica Slovaca, 15, 116-128.

D'Eon, R.G. (2004). Snow depth as a function of canopy cover in a forested ungulate winter range in southeast British Columbia. BC Journal of Ecosystems and Management, 3, 1-9.

Dublan, L. \& Jánošová J. (1991). Geologická stavba kaldery Polany. Stredné Slovensko, Prírodné vedy, 10, 95-110.

Durand, M. (2011). Snow water equivalent. In V.P. Singh, P. Singh \& U.K. Haritashya (Eds.), Encyclopedia of snow, ice and glaciers (pp. 170-171). London: Springer.

Elder, K., Dozier, J. \& Michaelsen J. (1991). Snow accumulation and distribution in an alpine watershed. Water Resources Research, 27, 1541-1552. DOI: 10.1029/91WR00506.

Elder, K., Rosenthal, W. \& Davis R.E. (1998). Estimating the spatial distribution of snow water equivalence in a montane watershed. Hydrological Processes, 12(10-11), 1793-1808. DOI: 10.1002/(SICI)10991085(199808/09)12:10/11<1793::AID-HYP695>3.0.CO;2-K.

Essery, R., Bunting, P., Hardy, J., Link, T., Marks, D., Melloh, R., Pomeroy, J., Rowlands, A. \& Rutter N. (2008). Radiative Transfer Modeling of a Coniferous Canopy Characterized by Airborne Remote Sensing. Journal of Hydrometeorology, 9, 228-241. DOI: 10.1175/2007JHM870.1.

Golding, D.L. \& Swanson R.H. (1986). Snow distribution patterns in clearings and adjacent forest. Water Resources Research, 22, 1931-1940. DOI: 10.1029/WR022i013p01931.

Gömöryová, E., Gregor, J., Pichler, V. \& Gömöry D. (2006). Spatial patterns of soil microbial characteristics and soil moisture in a natural beech forest. Biologia, 61, 329-333. DOI: 10.2478/s11756-006-0183-9.

Grünewald, T. \& Lehning M. (2011). Altitudinal dependency of snow amounts in two small alpine catchments: can catchment-wide snow amounts be estimated via single snow or precipitation stations?. Annals of Glaciology, 52, 153-158. DOI: 10.3189/172756411797252248.

Grünewald, T., Stötter, J., Pomeroy, J.W., Dadic, R., Moreno Baños, I., Marturià, J., Spross, M., Hopkinson, C., Burlando, P. \& Lehning M. (2013). Statistical modelling of the snow depth distribution in open alpine terrain. Hydrological Earth System Sciences, 17, 3005-3021. DOI: 10.5194/hess-17-3005-2013.

Hedstrom, N.R. \& Pomeroy J.W. (1998). Measurements and modelling of snow interception in the boreal forest. Hydrological Processes, 12, 1611-1625. DOI: 10.1002/(SICI)1099-1085(199808/09)12:10/11<1611::AIDHYP684>3.0.CO;2-4.

Holko, L. (2000). Evaluation of long-term snow cover data in a mountain catchment. Acta Hydrologica Slovaca, 1, 15.

Holko, L., Škvarenina, J., Kostka, Z., Frič, M. \& Staroň J. (2009). Impact of spruce forest on rainfall interception and seasonal snow cover evolution in the Western Tatra Mountains, Slovakia. Biologia, 64(3), 594-599. DOI: 10.2478/ s11756-009-0087-6.

Hríbik, M., Majlingová, A., Škvarenina, J. \& Kyselová D. (2009). Winter snow supply in small mountain watershed as a potential hazard of spring flood formation. In K. Střelcová, C. Matyas, A. Kleidon, M. Lapin, F. Matejka, M. Blazenec, J. Škvarenina \& J. Holécy (Eds.), Bioclimatology and Natural Hazards (pp. 119-128). Netherlands: Springer. DOI: 10.1007/978-1-4020-8876-6 10.

Hríbik, M., Vida, T., Škvarenina, J., Škvareninová, J. \& Ivan L. (2012). Hydrological effects of Norway spruce and European beech on snow cover in a mid-mountain region of the Polana Mts., Slovakia. Journal of Hydrology and Hydromechanics, 60, 319-332. DOI: 10.2478/v10098-012-0028-x.

Jain, S.K., Goswami, A. \& Saraf A.K. (2009). Role of elevation and aspect in snow distribution in Western Himalaya. Water Resources Management, 23(1), 71-83. DOI: 10.1007/s11269-008-9265-5.

Jost, G., Weiler, M., Gluns, D. \& Alila, Y. (2007). The influence of forest and topography on snow accumulation and melt at the watershed-scale. J. Hydrol., 347, 101-115. DOI: 10.1016/j.jhydrol.2007.09.006. 
Kadlec, V. \& Kovář P. (2008). Use of rainfall-runoff model KINFIL on Hučava catchment (in Slovak). Správy Lesníckeho Výskumu, 53, 211-222.

Kirchner, P.B., Bales, R.C., Molotch, N.P., Flanagan, J. \& Guo Q. (2014). LiDAR measurement of seasonal snow accumulation along an elevation gradient in the southern Sierra Nevada, California, Hydrological Earth System Sciences, 18, 4261-4275. DOI: 10.5194/hess-184261-2014.

Kuz'min, P.P. (1960). Snow accumulation and methods of estimating snow water equivalents (in Russian). Hydrometeoizdat.

Lehning, M., Löwe, H., Ryser, M. \& Raderschall N. (2008). Inhomogeneous precipitation distribution and snow transport in steep terrain. Water Resources Research, 44, W07404. DOI: 10.1029/2007wr006545.

Litaor, M.I., Williams, M. \& Seastedt T.R. (2008). Topographic controls on snow distribution, soil moisture, and species diversity of herbaceous alpine vegetation, Niwot Ridge, Colorado. J. Geophys. Res.-Biogeo., 113, G02008. DOI: 10.1029/2007jg000419.

Liu, C., Ikeda, K., Thompson, G., Rasmussen, R., \& Dudhia J. (2011). High-resolution simulations of wintertime precipitation in the Colorado Headwaters Region: Sensitivity to physics parameterizations. Monthly Weather Review, 139, 3533-3553. DOI: 10.1175/mwr-d-11-00009.1.

Lopez-Moreno, J.I. \& Vicente-Serrano S.M. (2007). Atmospheric circulation influence on the interannual variability of snow pack in the Spanish Pyrenees during the second half of the 20th century. Hydrology Research, 38, 33-34. DOI: 10.2166/nh.2007.030.

Lopez-Moreno, J.I. \& Stähli M. (2008). Statistical analysis of the snow cover variability in a subalpine watershed: Assessing the role of topography and forest, interactions. J. Hydrol., 348, 379-394. DOI: 10.1016/j.jhydrol.2007.10.018.

López-Moreno, J.I., Revuelto, J., Fassnacht, S., Azorín-Molina, C., Vicente-Serrano, S. M., Morán-Tejeda, E. \& Sexstone G. (2015). Snowpack variability across various spatio-temporal resolutions. Hydrological Processes, 29, 1213-1224. DOI: 10.1002/hyp.10245.

Luce, C.H., Tarboton, D.G. \& Cooley K.R. (1998). The influence of the spatial distribution of snow on basin-averaged snowmelt. Hydrological Processes, 12, 1671-1683. DOI: 10.1002/(SICI)1099-1085(199808/09)12:10/11<1671::AIDHYP688>3.0.CO;2-N.

Lundquist, J.D. \& Dettinger M.D. (2005). How snowpack heterogeneity affects diurnal streamflow timing. Water Resources Research, 41, W05007. DOI: 10.1029/2004wr003649.

Mindáš, J. \& Škvarenina J. (1995). Chemical composition of fog cloud and rain snow water in Biosphere Reserve Pol'ana. Ekológia (Bratislava), 14, 125-137.

Mindáš, J. (2003). Characteristics of snow cover regime in forest stands of midmountain region Polana (in Slovak). Lesnícky Časopis, 49, 105-115.

Peng, S., Piao, S., Ciais, Ph., Friedlingstein, P., Zhou, L. \& Wang T. (2013). Change in snow phenology and its potential feedback to temperature in the Northern Hemisphere over the last three decades. Environmental Research Letters, 8, 014008. DOI: 10.1088/1748-9326/8/1/014008.

Pomeroy, J.W., Parviainen, J., Hedstrom, N.R. \& Gray D.M. (1998). Coupled modelling of forest snow interception and sublimation. Hydrological Processes, 12, 1592-2337. DOI: 10.1002/(SICI)1099-1085(199812)12:15<2317::AIDHYP799>3.0.CO;2-X.

Pomeroy, J.W., Gray, D.M., Hedstrom, N.R. \& Janowicz J.R. (2002). Prediction of seasonal snow accumulation in cold climate forests. Hydrological Processes, 16, 3543-3558. DOI: 10.1002/hyp.1228.

Roe, G.H. \& Baker M.B. (2006). Microphysical and geometrical controls on the pattern of orographic precipitation. Journal of Atmospheric Science, 63, 861-880. DOI: 10.1175/jas3619.1.

Talbot, J., Plamondon, A.P., Lévesque, D., Aubé, D., Prévos, M., Chazalmartin, F. \& Gnocchini M. (2006). Relating snow dynamics and balsam fir stand characteristics, Montmorency Forest, Quebec. Hydrological Processes, 20, 1187-1199. DOI: 10.1002/hyp.5938.

Toews, D.A. \& Gluns D.R. (1986). Snow accumulation and ablation on adjacent forested and clearcut sites in southeastern British Columbia. In Western Snow Conference (USA), 15-17 April 1986 (pp. 101-111). Phoenix, Arizona (USA).

Trujillo, E., Ramirez, J.A. \& Elder K.J. (2007). Topographic, meteorologic, and canopy controls on the scaling characteristics of the spatial distribution of snow depth fields. Water Resources Research, 43, 1-17. DOI: 10.1029/2006WR005317.

Winkler, R.D., Spittlehouse, D.L. \& Golding D.L. (2005). Measured differences in snow accumulation and melt among clearcut, juvenile, and mature forests in southern British Columbia. Hydrological Processes, 19, 51-62. DOI: 10.1002/hyp.5757. 